\title{
Salutati, Ficino in Machiavelli: Od jajca do jabolka civilnega humanizma
}

\section{Jernej Šček* in Igor Škamperle**}

Če je res, da moramo o renesančnem humanizmu razmišljati kot o dobi "prerojenja, prebujenja, novega življenja «, ${ }^{1}$ je prav tako res nasprotno, da »je ta svet prej tragičen kot srečen, prej težek in krut kot pomirjen, bolj pogosto enigmatičen in nemiren kot čist in harmoničen «. ${ }^{2}$ Dovolj je že slepo odpreti Petrarkovo Pesmarico, da ujamemo nemirno dvojnost, ki humanizem uglašuje $\mathrm{z}$ bivanjsko stvarnostjo človeka, vse od historičnega očeta do sodobnih dedičev.

Družbena etika italijanskega humanizma od srede 14. do začetka 16. stoletja temelji na individualističnem etosu novega družbenega razreda, trgovskega meščanstva, za katerega se religiozni, ${ }^{3}$ specifično katoliški vrednotni sistem ne le prepleta, temveč oplaja in razcveta $\mathrm{v}$ svetnem, ne da bi s tem pristrigel katero od (protorazsvetljenskih) kali laičnih svoboščin, še več: s tem jih v modernem smislu celo utemeljuje. Vexata quaestio zgodnjemodernega civilnega krščanstva je razločno ubesedena pri Gilsonu: »Kako naj bomo v svetu, ne da bi bili od sveta? $\aleph^{4}$ Poznosrednjeveški miselni in duhovni premislek laične družbene etike $\mathrm{v}$ aristokratskem kontekstu dozori kot umotvor poklicnih politikov, ki so utelešali soodvisnost dejavnega (vita activa) in kontemplativnega

* Državni znanstveni licej Franceta Prešerna, Vrdelska cesta 13/1, 34128 Trst; jernejscek@hotmail.com.

** Filozofska fakulteta Univerze v Ljubljani, Aškerčeva 2, 1000 Ljubljana; igor.skamperle@ff.uni-lj.si.

1 Garin, La cultura, 7.

2 Ibid..

3 Pellegrini, Religione e umanesimo, 6-7.

4 Gilson, Ljubezen filozofov, 67. 
življenja ( vita contemplativa), Marte in Marije $\mathrm{k}^{5}$ alificirane, skozi politično delovanje aktualizirane in filozofsko motrenje poživljene človeškosti (bíos).

$\mathrm{V}$ pričujočem prispevku raziskujemo civilni živec renesančnega humanizma, in sicer vprašanje dotikanja in odmikanja etike in politike v historični ontogenezi, ki se - prej skozi didaktično kakor analitično prizmo - začne s Salutatijem, razvija s Ficinom in sklepa z Machiavellijem. Zazrli se bomo torej ab ovo usque ad mala, ${ }^{6}$ od jajca do jabolka civilnega humanizma. Ali je - tako tedaj kot danes - mogoče in celo nujno razmišljati o sodelovanju med etiko in politiko? »Ali nimata nič skupnega, kot se je včasih izjavljalo? Ali je res nasprotno, da nekakšna >etika velja za politiko kakor za katerokoli delovanje? «? Ali bi filozofija morala premisliti svojo človeško vlogo in vnovič služiti življenju (philosophia ancilla vitae) kot nekakšna služabnica »sui generis, ki se ne klanja zunaj-filozofskim silnicam - teologiji, zdravemu razumu, znanosti, tehniki, zgodovini ali politiki - temveč življenju samemu«? ${ }^{8}$ Velikani civilnega humanizma dokazujejo, da je pogoj pravične politike dober posameznik. Kdaj, če ne zdaj??

\section{ZALET Z NIČTE TOČKE ČLOVEŠKOSTI}

Pogoj za motrenje prometejske dobe prenove (renovatio), ki jo od zgodovinarja Julesa Micheleta (1798-1874) izpeljujemo iz francoščine (renaissance), je določitev epistemološkega ground zero, paradigmatskega brega v somraku "modernih «, ki so "vse pobarbarili «, ${ }^{10}$ če naj se - resnici na ljubo nekoliko protiintuitivno - izrazimo z besedami Petrarkovih sodobnikov, ki se jim je zdelo, da je srednjeveška sholastična filozofija doživela nekakšen intelektualni in duhovni zastoj. To ničto točko človeškosti ${ }^{11}$ postavljamo v poznosrednjeveški nauk (prej antropološkega kot kozmičnega) prezira do sveta, kot ga utemeljuje

5 Humanist Cristoforo Landino (1424-1498) v delu Disputationes Camaldulenses (Razprave v Kamáldoliju, 1474) aplicira svetopisemski prizor (Lk 10,38-42) na dva krščanska bivanjska sloga: Martino dejavno in Marijino kontemplativno življenje.

6 Horacij, Satire 1.3.6.

7 Weber, La politica, 99.

8 Arendt, Humanitas mundi, 26.

9 Pirkei Avot 1.14.

10 Garin, La cultura, 16; delno Škamperle, Magična renesansa, 18.

11 Soavtor Šček pričujočo sintagmo vnaša v prispevek »Med bedo in dostojanstvom: Neuresničeni antropološki diptih Lotaria iz Segnija (papeža Inocenca III.) «, ki bo objavljen v reviji Edinost in dialog. 
ena najbolj značilnih besednih proklamacij asketskega krščanstva, razprava v treh knjigah iz leta 1195 De miseria humanae conditionis ( $O$ bedi človeškega stanja) Lotaria iz grofovske družine Segni (1161-1216), ki bo tri leta kasneje zasedel Petrovo stolico pod imenom Inocenc III. V starih in modernih izdajah je sicer ena največjih književnih uspešnic na prelomu visokega in poznega srednjega veka zaslovela pod naslovom De contemptu mundi (Prezir do sveta). Na odru zahodnega premišljanja človeške minljivosti se brez sledov duhovne poučnosti, pojmovne metafizike ali abstraktne idejnosti odvije pravi spektakel smrti, ${ }^{12}$ teocentrični protihumanizem surove telesnosti. Z grozljivim hiperrealizmom je predstavljena brezčasna usoda trpljenju usojenega ${ }^{13}$ bitjeca, človečka, ${ }^{14}$ bolj zverinskega od živali, ${ }^{15}$ ki telesno in moralno razpada. ${ }^{16}$ Človekova uklenjenost v nizkotno bedo je v Lotarijevi asketiki absolutno, neobvladljivo in določujoče dejstvo, kajti jabolko ne pade daleč od drevesa. ${ }^{17}$ Prebliske sočutja, ${ }^{18}$ ki se vraščajo v eksistencialistični tok do Pascala, ${ }^{19}$ preglasi »inkvizitorni« seznam krivoverstev, ki mu ni videti konca, ${ }^{20}$ toliko, da avtor svoje odrešenjske upe polaga na konec, pričakovaje katarzično apokalipso ${ }^{21} \mathrm{z}$ morbidno naklonjenostjo do smrti, tako sumljivo, da bo delo kasneje prišlo na Index librorum prohibitorum. Ne preseneča, da med več kot 400 biblijskimi sklici prednjačijo tisti iz Pridigarja (Koheleta) na čelu s protisvetnim Vanitas vanitatum et omnia vanitas. ${ }^{22}$

Toda Lotarijevo tematsko in slogovno mračnjaštvo, retrogardnost in ljudomrzna nečloveškost so le pol resnice. Pri Lotariju je bistveno

Glej Gigliucci, Lo spettacolo della morte.

Lotario, De contemptu mundi 1.11.1.

Alberti v drugi knjigi dialoga Teogenij človeško bedo opredeli s samostalnikom iz ljudske govorice omicciuolo, španski duhovnik Juan Ginés de Sepúlveda (1490-1573), teoretik naravne podložnosti ameriških staroselcev in pravične osvajalske vojne konkvistadorjev, pa z latinskim homunculus.

Lotario 1.19.3.

Lotario 1.1.3.

Lotario 1.8.1-2.

Lotario 1.14.1.

„Človek je le trst, v vsej naravi najšibkejši; in vendar trst, ki misli. Da se zlomi, ni treba, da se vse sile vesolja zgrnejo nadenj: sapica, kapljica vode ga more ubiti. A tudi če bi vse vesolje zgrmelo nanj, bi bil človek še vedno odličnejši od tega, kar ga ubija, ker ve, da umira in da ima vesolje premoč nad njim. Vesolje pa o tem ne ve ničesar.« Pascal, Misli, frg. 247, 122

Lotario 3.1.4.

Lotario 3.20.3.

Prd 1,2;12,8. 
to, kar manjka. Pisec že v prvih odstavkih predgovora ${ }^{23}$ napoveduje, da se je namenil napisati nadaljevanje, v katerem bi opeval in poveličal božjega sina, s čimer bi kronal dvojni značaj antropološkega problema in de facto ubesedil prvo "moderno « razpravo o človeškem dostojanstvu (dignitas hominis). Četudi salto mortale ni uspel, je Lotario humanistično seme zasadil in potentia ter s tem dokazal, da lahko razmislek o dostojanstvu človeka vzklije le iz treznega uvida o tragičnosti človeškega stanja (miseria humanae conditionis). Humanistični odgovor na večno enigmo človeka je dvogoriščen: bitje blišča in bede smo, upanja in dvoma, ljubezni in obupa. „Če ne ohranimo sonavzočosti obeh polov, med katerima neizčrpno niha drama človeškega vprašanja v svoji historičnosti, tvegamo človeka uporabiti kot pretvezo za prazno zatrapanost, v kolikor se enoznačno proslavlja njegova veličina, ali za stokajočo, morda celo grajajočo lamentacijo v primeru, da se poudarja le njegovo bedo. ${ }^{24} \mathrm{Z}$ zaletišča, ki ga določa contemptus mundi, je torej mogoče izpeljati uvodni sklep: humanistični obrat k delovanju (v človeški svetnosti za božjo slavo), vita activa, zraste iz asketsko kontemplativnih korenin $\mathrm{v}$ media aetas. Njegovo izhodiščno obzorje je aristotelizem, ${ }^{25} \mathrm{da}$, prav tista tisočletna auctoritas (ipse dixit). ${ }^{26}$

Premišljanje in ozaveščanje človeške bede s prihodom Petrarke in Salutatija ni izginilo, postalo je latentno in se preoblikovalo v secretum. ${ }^{27}$ Kontemplativna ločitev od sveta je po novem kakor poživljajoči vzdih, potreben premor med dejavnima robovoma življenja. Lotarijevsko izročilo so sicer zvesto prevzeli mnogi, denimo frančiškan Bernardin iz Siene (1380-1444), eden največjih pridigarjev quattrocenta, humanist, ki je vzgajal humaniste, ${ }^{28}$ Piccolominija in primis. Frančiškanski prezbiter Bernardin iz Felter (1439-1494) je svoje pridige začenjal s pozivom k zaničevanju svetnosti: Nolite diligere mundum. Do Pascala pa so sledili vsaj še Landino, Alberti, Machiavelli, Montaigne. Pesimistični razplet renesanse je torej v historičnem humanizmu prisoten vse od začetka. Ni pesimistični obrat, temveč temni obraz humanizma. Če Lotario

Lotario Predg. 2.

Pellegrini, Umanesimo, 23; glej še Cappelli, La dignità e miseria dell'uomo.

Garin, Aristotelismo e platonismo.

Galilei, Dialog, 108; 110.

Petrarkov notranji nemir (travaglio interiore) sili iz dela Moja skrivnost, prozne mojstrovine v treh knjigah. O njegovem obstoju so vedeli le najbližji, denimo Boccaccio, dokler ga ni v letih $1378-88 \mathrm{v}$ padovanskem skriptoriju prepisal florentinski redovnik in humanist Tedaldo della Casa. Zasebni spis je postal postumno delo, Secretum kot skrivnost in ločitev od sveta.

8 Prim. Garin, Educazione umanistica in Italia, 45-51. 
iz Segnija predstavlja simbolno fiksacijo človeka nazaj in navzdol, ${ }^{29}$ sta si Petrarka in Salutati drznila pogledati naprej in navzgor - in v tostranstvu uzrla odkruške božanske svetosti.

\section{HUMANI(STIČNI) HOMO POLITICUS}

Coluccio Salutati (1332-1406) je nedvomno prvorojenec in prvak civilnega humanizma. Rojen v kraju Stignano v dolini Valdinievole februarja $1332,{ }^{30}$ je v Florenci sprva prodrl kot pravnik in trgovinski notar, dokler ni aprila $1375^{31}$ stopil na vrh političnega Parnasa z izvolitvijo za kanclerja sinjorije, najprestižnejše politične funkcije v mestu po vladarju. Eden najbolj prodornih in emblematičnih mislecev svojega časa, "posvojeni sin Florence $", 32$ je častno vlogo ob boku Medičejcev opravljal dobra tri desetletja. ${ }^{33}$ Kot prispodoba, danes bi rekli, javnega intelektualca ${ }^{34}$ je renesančni mandarin deloval v kontekstu, v katerem človek velja toliko, kolikor deluje v socialnem tkivu mestne države. Dej humanista nikdar ni aktivizem, dejanje zaradi dejanja samega, temveč vselej etična reakcija osebne vesti. Salutati kot civilno angažirani, ambiciozni, podjetni, socialno spretni in volitivni duh, ki je od mladih nog sanjal o politiki in upal, da mu bo na nagrobniku pisalo, kako je bil v življenju florentinski kancler. ${ }^{35}$

Kovačnica intelektualnega vrenja ob reki Arno je bil samostan Svetega Duha z bogato knjižnico, ki je stal ob istoimenski baziliki. Briljantni krožek često golobradih polihistorjev je z znanstvenimi študijami in političnimi funkcijami razvijal novo pojmovanje an-

Slovenska ikonografska tradicija odpira čudovito okno v svet antropološkega pesimizma, ki se ujema tako z lotarijevskim kakor s poznorenesančnim obzorjem. Fresko Sveta Nedelja slikarja iz kroga Janeza Ljubljanskega (okr. 1460) na pročelju cerkve Marijinega oznanjenja v Crngrobu lahko umestimo v kontekst bogatega imaginarija triumfov smrti (Pieter Bruegel starejši, Hieronymus Bosch in nasploh vsa severnoevropska, neromanska renesansa) ter mrtvaških plesov (tudi Janeza iz Kastva iz cerkvice Svete Trojice v Hrastovljah). Dolgo časa je veljalo, da se je bil rodil leto poprej, a Campana, Martelli, Nuzzo idr. so dokazali nasprotno.

31 Ohranjen je uradni dokument ob prvi izvolitvi z dne 19. aprila 1375 (Salutati, Epistolario, Appendice 3.4, 4. del, 437-438).

32 Ullman, The Humanism, 75.

33 Glej De Robertis, Tanturli in Zamponi, Coluccio Salutati; Cardini in Viti, Coluccio Salutati.

34 Chomsky, »Odgovornost intelektualcev«; Arendt, Men in Dark Times.

35 Pismo Benvenutu iz Imole, 22. maja 1375 (Salutati, Epistolario 3.19, 1. del, 201204). 
gažiranega življenja, ki ga od leta 1928 zlasti v anglosaškem miljeju imenujejo civilni humanizem. ${ }^{36}$

Salutati je nesporni dedič in najzvestejši naslednik Petrarkovega izročila, ${ }^{37}$ vse od učiteljeve smrti leta 1374 do svoje leta $1406,{ }^{38}$ pravi trait d'union med protohumanizmom treh florentinskih vencev (Dante, Petrarka, Boccaccio) in prvo generacijo humanistov quattrocenta, predvsem Leonardom Brunijem (Areškim) in Poggiom Bracciolinijem, ${ }^{39}$ pa tudi Petrom Pavlom Vergerijem starejšim, ${ }^{40}$ in se je pri njem, ki je bil communis omnium magister ${ }^{41}$ zgledoval za pisanje prve humanistične pedagoške razprave De ingenuis moribus et liberalibus studiis adulescentiae (1402). Salutati se ni s Petrarko nikdar srečal osebno, ${ }^{42}$ zato pa velja pobrskati po njegovih stikih s Petrarkovim prijateljem in dopisovalcem Francescom Nellijem (umrl 1363), notarjem florentinske kurije. S sveže izvoljenim priorjem florentinske cerkve svetih Apostolov si je izmenjal pismi, ki ju imamo nasploh za najstarejši. ${ }^{43}$ Prvo od prvih, napisano pred poletjem $1363,{ }^{44}$ že vsebuje kali življenjskega poslanstva bodočega florentinskega kanclerja. Salutati poje hvalnice o plemeniti, torej udejanjeno krepostni drži obeh, ki širšo skupnost za sabo »vlečeta $\mathrm{k}$ dobremu«. Na osnovi izkušnje poslednjih dni Sokrata ${ }^{45}$ in stoiških naukov, ${ }^{46}$ ki vzgajajo k zgledu kot nadteoretski, doživljajski šoli življenja, je humanistom po meri predvsem moralna filozofija, danes bi rekli uporabna ali praktična etika, ${ }^{47}$ tista, ki dviguje

Bürgerhumanismus je skovanka nemško-ameriškega raziskovalca Hansa Barona; glej Baron, Crisis of the Early Italian Renaissance; Pocock, Machiavellian Moment; Hankins, Renaissance Civic Humanism; ter Baron, »Lo sfondo storico«.

Garin, L'umanesimo italiano, 34.

Ullman, Humanism, 39.

Še vsaj Francesco Nelli, Lapo iz Castiglionchia in Zanobi iz Strade. Prim. Cappelli, L’umanesimo italiano, 86, glej še Ullman, Humanism, 39-49.

Iz pisma, ki ga Vergerij pošlje Salutatiju iz Padove 31. januarja 1391 (Smith, Epistolario 28, 55).

1 Salutati, Epistolario, Appendice terza 16, 4. del, 473, in ibid. 17, 479.

42 V dvoletju 1368/69 sta si izmenjala pet zgoščenih pisem: prvega Salutati podpisuje v Montefiasconeju 11. septembra 1368 (2.4), potem si sledijo še 2.8, 2.11, 2.15 in 2.16 (Salutati, Epistolario, 1. del, od 61 dalje).

Novati in Ullman.

Salutati, Epistolario, Epistole aggiunte 1, 4. del, 241-245. Glej Platonovo »sokratsko« trilogijo Apologija, Fajdon in Kriton.

Prim. Seneka, Pisma prijatelju Luciliju 11.8, O srečnem življenju 1.2, O prostem času 1.1.

7 Singer, Praktična etika. 
kvasovko praktične razumnosti..$^{8}$ Humanizem je odgovor na klic vesti $\mathrm{k}$ moralni odgovornosti. Homo politicus živi zase in deluje za druge $\mathrm{v}$ zemeljskem mestu zato, da bi v postal prebivalec nebeškega Jeruzalema. ${ }^{49}$ Salutatijevo poveličevanje sokratskega državljanstva ${ }^{50}$ požene filozofsko etiko $\mathrm{v}$ protomoderno politično filozofijo. ${ }^{51}$ Piše se civilni manifest krščanskega antropološkega optimizma, ${ }^{52}$ upanja $\mathrm{v}$ potencialnost človečnosti in vere $\mathrm{v}$ presežnost človeškosti, ki odpira vprašanje razmerja med svetim in svetnim - ne zato, da bi ga ovrglo, temveč da bi ga bolje utemeljilo.

Izhodišče renesančne politične filozofije je korak filozofske antropologije: protiasketska in protisholastična, mestoma protiredovniška, vselej laiško krščanska rehabilitacija aristotelskih ${ }^{53}$ in ciceronskih ${ }^{54}$ etičnih naukov o socialnih vrlinah in civilnih dolžnostih. Drugače rečeno, prebujenje utilitaristično-pragmatične etike odgovornosti (povedano webrovsko). ${ }^{55}$ Civilno krščanstvo je pod plaščem rimske kurije v času zahodnega razkola (1378-1417) doživljalo globoko moralno nelagodje, ${ }^{56}$ pravi duhovni pretres, pa vendar je dokazalo družbenoetično zrelost iz zavesti, daleč od najstniških idealizmov, »da svetu vladajo demoni in kdor se ukvarja s politiko - to pomeni $\mathrm{z}$ močjo in nasiljem - sklene dogovor $\mathrm{z}$ demonskimi silami in, kar se tiče njegovega delovanja, ni res, da iz dobrega nastaja le dobro in iz slabega le slabo, ${ }^{57}$ temveč se pogosto dogaja nasprotno. Kdor tega ne vidi, je dejansko politično nezrel. $\aleph^{58}$

Umetnost življenja (ars vivendi) je za civilne humaniste izmenjavanje socialno osmišljenih praktičnih odločitev in refleksivnih trenutkov zasebnega premora. Filozofska etika se s humanisti zaveže zemlji, prizemlji, a nikdar ne v pritlehnosti. Kot polje sklepanja civilnih

Struever, Theory as Practice.

Garin, L'umanesimo, 8.

Salutati je, tako kot kasneje Manetti, velik zagovornik teze, po kateri je Sokrat praoče vseh moralistov, prvi veliki preučevalec »človeške modrosti« (prim. Platon, Apologija 28e-3oe).

1 Dodatni zagon novoveški politični teoriji vdahne Bartolomeo Sacchi (Il Platina) z Lorenzu Medičejcu posvečenim dialogom De optimo cive (O dobrem državljanu) iz leta 1474.

Gilson, Duh srednjeveške filozofije, 117-139.

Aristotel, Nikomahova etika 1.6.1097b-1098a.

Ciceron, $\mathrm{O}$ državi 1.2-3.

Weber, La politica, 102.

Pellegrini, Religione e umanesimo, 130-136.

Glej Mt 7,17.

Weber, La politica, 105. 
kompromisov se filozofska etika preoblikuje v družbeno. Ne prezirati ali bežati, temveč sprejemati življenjske izzive, se truditi spreminjati svet, želeti si boljšega, moralno odgovarjati socialni odgovornosti in vstopati v prvo frontno črto: Standum in acie. ${ }^{59} \mathrm{~S}$ humanizmom se politika moralizira in postaja civizem. Za humaniste je filozofsko relevantno tisto, kar človeka počlovečuje, kar ga dela boljšega. ${ }^{60}$ Stremljenje k dobroti nas približuje k drugemu bolj od spoznanja resnice. ${ }^{61}$

Ne smemo spregledati družbenoetičnih smotrov Platonove prispodobe o votlini. ${ }^{62}$ Ko se modrec po neskončnih mukah izvije na plano, je šele na pol poti, vrh gore, s katere je mogoče samo sestopiti. V votlino se mora razumnik vrniti, da bi bivšim sojetnikom pokazal prevaro videza in tudi njim pomagal do sončne resnice. Ta tvegani spust nazaj, med množico slepcev, iz katere tudi sam izhaja, je filozofska pot v politični pekel, saj sta resnica in pravica soodvisni. Platonova votlina ni le spoznavoslovni poziv - k razumevanju dobrega, pravice, resnice - temveč hkrati in predvsem etični klic k odgovornosti do drugega in k skrbi za drugega. Historični humanisti so, po Sokratovem zgledu, etični intelektualisti: prepričani, da vsak pravi spoznavni proces nosi etične implikacije in posledice, da se s spoznavno emancipacijo (resnico) svet izboljšuje v smeri pravičnosti in dobrote. Temu brezčasno razsvetljenskemu smotru se humanizem še danes noče odpovedati.

Etični temelj salutatijevstva ${ }^{63}$ najdemo v pismu Robertu Guidiju, grofu iz Battifolleja, z dne 16. avgusta $1374 \cdot{ }^{64}$ Poveličani so filozofi, ki "vzgajajo dušo«, in očrnjeni tisti, ki se utapljajo v praznih sholastičnih disputih. Na stopničko brez konkurence dvigne Petrarko »kot filozofa, kot človeka in kot kristjana «, zanj - in tisti čas mnoge druge - presega samega Danteja, kajti ima ga za začetnika samozavedanja in kritičnega ločevanja med antičnimi (antiqui) in modernimi (moderni). ${ }^{65}$ "Moderni sofisti«, kot sam imenuje srednjeveške sholastike, ne iščejo resnice, temveč zmagovalno zatočišče za svoje argumente, kakor predsokratika Protagora in Gorgija, s to razliko, da so prvi eristično uporabljali dia-

61 Petrarka v delu De ignorantia zapiše: "Satius est autem bonum velle quam verum nosse «, citirano po Pellegrini, Religione e umanesimo, 278.

62 Platon, Država 7.514a-517a.

63 Ullman, The Humanism, 85.

64 Salutati, Epistolario 3.15, 1. del, 176-187.

$65 \mathrm{~V}$ pismu Giovanniju Bartolomeiu z dne 13. julija 1379 Petrarko postavlja tik za Cicerona: če so veliki pesniki kakor reke - Ovidij kot Ticino, Lukan kot Rodan, Vergilij kot Eridan - je Petrarkovo veličino moč primerjati le z morjem (Salutati, Epistolario 4.20, 1. del, 334-342). 
lektiko, drugi pa retoriko. Še enkrat: Petrarka nad Dantejem, Vergilij nad Homerjem, ${ }^{66}$ Ciceron nad Platonom.

Oris politične misli zgodnjega humanizma ${ }^{67}$ je najti v Salutatijevem dolgem pismu Karlu III. Neapeljskemu (1345-1386), grofu AnžujskoDraškemu iz leta $1381,{ }^{68} \mathrm{kjer}$ se avtor zgleduje pri Petrarkovem dopisu Robertu I. Neapeljskem (1277-1343). ${ }^{69} \mathrm{~V}$ pismu utemeljuje značilno ločevanje med monarhično avtoriteto in tiranstvom ${ }^{70} \mathrm{z}$ določitvijo, kakšne virtutes so potrebne dobremu vladarju, $\mathrm{s}$ tem, da razumni suveren vlada svobodnim državljanom, ne sužnjem. Ullman postavi tezo, da je v Karlu III. morda videl nekakšnega "razsvetljenega absolutista", ki bi zmogel zediniti italske državice, ${ }^{71}$ tako kot je Dante svoje upe polagal v Henrika vir. Luksemburškega, ${ }^{72} \mathrm{~s}$ čimer je kajpak prej mislil na (utopično) restavracijo antičnega Rima, tokrat pod cesarsko krono papeštva, kot na podrejanje SRC. Salutatijevska apologija florentinske svobode (Florentina libertas) izhaja iz prepričanja, da je mesto ob Arnu polnomočni dedič državniške kulture starega Rima. ${ }^{73}$ "Kaj pomeni biti Florentinec, če ne ravno biti - bodisi po rojstvu ali po zakonu - rimski državljan, to pomeni svobodnjak in nikdar suženj? : ${ }^{74}$

Ego de terra, lex vero de mente divina. Tako je interpret renesančnega humanizma Eugenio Garin (1909-2004) izluščil salutatijevski prispevek k dobi, ki »obrne hrbet naravi in se posveti življenju človeka«.75 Salutati ni bil filozof, toda njegov neizčrpni opus je filozofsko nadvse relevanten, kar lahko zatrdimo tudi za samega Petrarko. ${ }^{76}$ Salutatijev miselni sistem ni sistematično niti koherentno strukturiran, po svoji praktični usmerjenosti je prej pojmovni zarodek, bolj politika kot filozofija. Salutatijev obnovljeni interes za človeški svet je nedvomno odprl pot moderni zgodovini idej.77

Pismi Francescu Bruniju (Epistolario 4.8, 1. del, str. 267) in Pellegrinu Zambeccariju (Epistolario 9.2, 3. del, 13).

Cappelli, L'umanesimo, 76-77.

Salutati, Epistolario 5.6, 2. del, 11-46.

Glej Petrarkovo pismo Francescu iz Carrare (Seniles 4.1).

Salutati, De tyranno 4.14.

Ullman, The Humanism, 77.

»Duša knežja« Henrik viı. Luksemburški naj »ozdravi« Italijo, ki še ni državniško zrela (Dante, Raj 30.133-148).

3 Prim. pismo Antoniu di ser Chellu z dne 21. avgusta 1383 (Salutati, Epistolario 5.7, 2. del, 85-98).

Salutati, Invectiva, 54 .

Garin, L'umanesimo, 41.

Gentile, Studi, 14, 19 in 21.

Oestereich, Storia dei diritti umani, 51. 


\section{REPUBLIKANSKA VREDNOST BESEDE}

Salutati si je ugled med someščani pridobil s prefinjenim pisanjem uradnih dopisov, kot communis opinio stroke velja, da je filozofsko najzanimivejši del Salutatijevega opusa formalno nefilozofski. Njegov bajni epistolarij, zbirka 344 zasebnih dopisov, ki so bili v tistem času namenjeni javnemu branju, je prava zakladnica dialoških idej Iz nabora so, kot je velevala tedanja praksa, ${ }^{78}$ izpuščena uradna pisma, podpisana v imenu florentinske vlade. ${ }^{79}$ Salutatijeva korespondenca ni le med najobsežnejšimi vseh časov, temveč kanonizira nov literarni žanr tako, da mu nudi formalne smernice. Sodobni bralec se ne more načuditi nad količino besedil, mnogovrstnostjo vsebin, oblik in sogovornikov, interesov, ki se razcvetajo $» \mathrm{Z}$ živahnostjo in prodornostjo, ki nima para ${ }^{80}$

Epistolarij je odlično interpretacijsko izhodišče za dokazovanje tega, da je zgodovinsko-filološka tradicija humanizma v bistvu zahteva po razumnem dialogu, torej po kritičnosti, ki kliče $\mathrm{k}$ drugemu. Le kaj je boljše od navdihujočega pogovora z velikani antične modrosti, sicer na daljavo, pa vendar osebno - s pisemsko izmenjavo. Staremu prijatelju vendar moraš napisati pismo, pismo pokojniku, kot bi bil še med živimi! Salutatijev paradigmatski vzornik je kajpak Petrar$\mathrm{ka}^{8}{ }^{81}$ ki se tu prej kot na Cicerona opira na Senekova Pisma Luciliju. Bernardin iz Siene je v čudoviti pridigi o studia humanitatis leta 1425 stvar zastavil takole:

Ali ne bi užival, ko bi lahko v živo videl ali poslušal pridig Jezusa Kristusa, svetega Pavla, svetega Avguština, Gregorja, Hieronima in svetega Ambroža? Hitro, pojdi in prebiraj njihova dela, ki ti najbolj ugajajo [...]; pogovarjal se boš z njimi in oni ti bodo spregovorili; prisluhnili ti bodo in ti jih boš poslušal. ${ }^{82}$

Da je Salutati najbrž najboljši epistolograf vseh časov, ${ }^{{ }_{3}}$ pričajo že historični viri, denimo uradni dokument ob drugi izvolitvi za kanc-

78 Griggio, »Dalla lettera all'epistolario«.

79 Nuzzo, Lettere di stato; sicer glej De Rosa, Coluccio Salutati.

80 Garin, Filosofi italiani, 81.

81 Zadnjo, 24. knjigo Petrarkovih pisem prijateljem (Familiares) sestavlja 13 pisem, od katerih je deset posvečenih pesnikovim vzornikom iz preteklosti, Antiquis illustrioribus, kot jim sam pravi v Familiares 24.2.6.

82 S. Bernardino da Siena, Le prediche volgari, citirano po Garin, Educazione umanistica in Italia, 8-9.

83 Tako npr. Marzi, La cancelleria, 149, in Ullman, Humanism, 113. 
lerja. ${ }^{84}$ Njegov življenjepisni sodobnik zgodovinar Filippo Villani (1325-1407) piše, da je ugledni dedič toskanske diplomatske tradicije Piccolomini proslavljal modrost florentinskih vladarjev zato, ker so na mesto kanclerja imenovali velike humaniste. Milanski vojvoda Giangaleazzo Visconti (1347-1402) naj bi med florentinsko vojno (1390) trepetaje pričakoval Salutatijeve zunanjepolitične epistole, saj da je avtorjevo pero nevarnejše od tisoč konjenikov ali celo od samega poraza na bojnem polju. ${ }^{85}$

Salutati je bil torej odličen diplomat zato, ker je bil dober humanist, vrhunski govornik, Ciceronis simia. ${ }^{86}$ Svojih retoričnih spretnosti, s katerimi je vodil zunanjo politiko Firenc, se je zavedal, saj tudi sam trdi, da moč učinkovitega izražanja, eloquentia, razločuje človeka od zveri. ${ }^{87}$ Colucciov slog je eruditski, svoje trditve in misli ilustrativno podpira $\mathrm{z}$ brezmejno bero klasičnih literarnih referenc, ki zapisano ovrednotijo in legitimirajo. Obnovljena vrednost govorništva in filologije, zvestoba virom in gojenje lepe besede imajo torej politično, civilno (vir civilis) vrednost. ${ }^{88}$ Govor in razum, filologija in politika, preteklost in prihodnost, kulturna vzgoja in aktivno državljanstvo, vse to je civilis sapientia. Humanistika kot osebna preizkušnja civilne odgovornosti. »Brez Danteja, Petrarke in Boccaccia ni humanizma in niti filozofije humanizma«. ${ }^{89}$ Brez človeškosti (humanitas) ne more biti politike, kaj šele dobrih politikov. Ni ga dobrega politika brez bogate in široke humanistične kulture. Humanizem je politična etika, ali vsaj etična politika.

\section{DOSTOJANSTVO MARLJIVEGA ABRAHAMA}

Družbena etika renesančnega humanizma je v svojem voluntarističnem zaletu praktična, progresivna, reformatorska, nemara junaška, zagotovo herkulska. ${ }^{\circ}$ Med Salutatijeva teoretsko ambicioznejša dela uvrščamo razpravo De laboribus Herculis (O Herkulovih junaštvih), $\mathrm{v}$ kateri se posveča hermenevtičnim, jezikoslovnim in literarnokri-

84 Salutati, Epistolario, Appendice 3.13, 4. del, 464-466.

85 Oboje Canfora, Prima di Machiavelli, 13; Villani, Le vite d'uomini illustri, xxiii, op. 6.

86 Novati med prilogami objavi zanimiv dopis ob latinski izdaji Villanijevega življenjepisa, ki ga avtor Salutatiju verjetno pošlje v predogled (Salutati, Epistolario, Appendice 3.21, 4. del, 487-495).

87 Prim. Salutati, Epistolario 2.9, 2.10 in 4.1.

88 Cacciari, La mente inquieta, 41; Skinner, Virtù rinascimentali, 17-52.

89 Ibid., 42.

90 Pellegrini, Religione e umanesimo, 100. 
tiškim vprašanjem o naslovnem junaku, ki ga je vzljubil z branjem Senekovih tragedij (Hercules furens in Hercules Oetaeus). ${ }^{91} \mathrm{~V}$ zahodno misel se s svojo avro vrača mit Herkulovega razpotja, ${ }^{92}$ pitagorejska arhetipska podoba črke Y, razpotja odločanja vesti med dobrim in zlim, tvegani aut-aut svobodne izbire, ki se preko grškega cerkvenega očeta Bazilija Velikega (329-379) navezuje nazaj na Ksenofonta in Cicerona (a ima korenine vsaj pri sofistih, verjetno pri Prodiku). Herkulovo ime humanizem inventivno, četudi etimološko napačno »izpeljuje « iz sintagme heros cleos, kjer se srečata korenjak in sloves, vir fortis et gloriosus. ${ }^{93}$

Humanizem je junaški toliko, kolikor možnosti človeka poganja v dejanskost. Človeka v naravnem stanju (homo) kot bitja potencialne humanitete žene v prihodnost do zrelega moža (vir), v smislu razvitega človeka udejanjene krepostnosti. ${ }^{94}$ Človečnost je uresničena človeškost. Junaški zanos ${ }^{95}$ je forma mentis tedanjega laičnega meščanskega etosa, ki stremi za veličino, uspehom, lepoto in večnostjo. Kakor brezčasni vzorniki Petrarka, Seneka, Ciceron in Horacij tudi Salutati zasleduje vzvišene, toda ne nemogoče cilje, dosedanje meje želi presegati, a nikdar čez mero.

Petrarka je prijatelju in spovedniku, avguštinskemu teologu in Boccaccievemu učitelju Dionigiju iz Borga San Sepolcro (okr. 1300-1342) namenil znamenito pismo, ${ }^{96} \mathrm{ki}$ išče bolj prisojno in varno pot do Boga, krščanskih resnic in presežne večnosti. Vnovič relevantna antropološka etika ohranja teocentrični smoter. Petrarkovo duhovno spreobrnjenje $\mathrm{e}^{97}$ se zgodi ob gorniškem vzponu na provansalski Mons Ventosus, Vetrnik. Vrednotna analogija med Petrarkovim pismom Dionigiju in epistolo Coluccia Salutatija prijatelju Pellegrinu Zambeccariju z dne 23. aprila $1398^{98}$ je kot na dlani:

91 Literarni zgodovinarji sicer zadnjega večinoma ne pripisujejo več Seneki.

92 Glej sliko Ercole al bivio (okr. 1595) poznega činkvečentista Annibala Carraccija (1560-1609).

93 Witt, Hercules at the Crossroads, 215; Cappelli, L'umanesimo italiano, 8o.

94 Pellegrini, Religione e umanesimo, 52-53.

95 O znamenitem Brunovem delu De gli eroici furori (O junaških zanosih) glej Škamperle, »Lovec in odstrta Diana«.

96 Petrarka, Familiares 4.1, glej Petrarka, »Vzpon na Mont Ventoux«.

97 Zanimivo bi bilo primerjati spreobrnitveni izkušnji Petrarke in Avguština. Ta v Izpovedih (10.29) opisuje, kako je iz sosedove hiše zaslišal glas: Tolle lege, tolle lege. Vzemi (knjigo) in beri! Če se je sam približal krščanstvu z branjem svetih spisov, se je Petrarka z branjem stoikov.

98 Salutati, Epistolario 10.16 (3. del, 285-308). 
Ne misli, Pellegrino moj, da k popolnosti vodi pot bega od množice, ogibanja pogledu na lepe stvari, zapiranja v samostan ali izmikanja na tihe pristave. Kar tvoje udejstvovanje ovenča s popolnostjo, je v tebi. V sebi nosiš moč, s katero vrednotiš zunanje dobrine tako, da te ne prizadevajo in te ne morejo prizadeti, če bosta le misel in duša ostali dovolj zbrani in se ne bosta iskali v zunanjem svetu. Če pustiš zunanjost izven duše, bodo ulica, trg, kurija in drugi obljudeni kraji zate kot pristava, kot oddaljena in popolna samota. [...] Le čemu lahko koristi samotarsko življenje? [...] Povej mi, dragi Pellegrino, kdo je Bogu ljubši: samotarski in brezdelni Pavel ali marljivi Abraham?99

Salutati pred prijateljem, ki namerava stopiti v samostan, zagovarja vlogo in pomen civilno dejavnega življenja, kajpak s sklicevanjem na Ciceronovo mojstrovino $O d r z ̌ a v i$, priljubljeno referenco moralistične tradicije quattrocenta. Salutati orje ledino renesančnih hvalnic človeškemu dostojanstvu (laudatio hominis), ki se bodo razcvetele v teoretskih razpravah Facia (okr. 1447), Manettija (1452) in Pica (1486). Ker na tem mestu ne moremo globlje, naj omenimo le izpričano ${ }^{100}$ anekdoto $\mathrm{z}$ neapeljskega dvora aragonskega kralja Alfonza v. Plemenitega (1396-1458), velikega renesančnega mecena, h kateremu je bil sredi stoletja v vlogi predstavnika florentinske republike vpoklican Manetti. Kralj ga je, razočaran nad naročeno Facievo knjižico De prestantia et excellentia hominis, izzval z vprašanjem, katero je človekovo specifično mesto v stvarstvu. Namesto odgovora mu je Giannozzo ponudil ciceronsko diktologijo ${ }^{101}$ agere et intelligere: človek je poklican, da $\mathrm{z}$ delovanjem in s spoznavanjem pusti v svetu sled človečnosti, telesno in duševno, dejavno in kontemplativno. Tako se rodi bržkone največja mojstrovina renesančnega antropološkega optimizma, Manettijeva razprava v štirih knjigah Dignitas et excellentia hominis (Dostojanstvo in odličnost človeka). Kot je pojasnil že Dante: ${ }^{102}$ plemenitost je tam, kjer so vrline, ni pa tudi obratno.

99 Prim. Jak 2,14-26.

100 Vespasiano, Vite di uomini illustri, 444-474.

101 Retorično figuro najdemo v izvirniku na koncu drugega verza 35. soneta Petrarkove zbirke pesmi Canzioniere: "Solo et pensoso i più deserti campi / vo misurando a passi tardi et lenti«, ki ga je Alojz Gradnik poslovenil v sonetu št. 16 takole: "Zamišljen, sam, najtožnejše pustinje / počasi merim s trudnimi koraki«; Petrarka, Soneti in kancone, 16.

102 Dante, Pekel 26.119. 


\section{VOLJA, USODA, VEST IN DRUŽBENO ZDRAVJE}

Renesančni humanizem v novi vek požene civilno avguštinski ${ }^{103}$ in krščansko stoiški ${ }^{104}$ nauk interiorizma, tisto poživilno "pot vase $\ll^{105} \mathrm{k}$ obdelovalni gradnji dušne notranjosti (cultura animi), ki približuje drugemu in dviga k presežnemu. Kakor v sestopu s preplezanega vrha gornik onemi, ${ }^{106}$ predelovaje prehojeno pot, striktno v tišini: ${ }^{107}$ »Kolikokrat, misliš, sem se tistega dne, ko sem se vračal, ozrl čez ramo in pogledal vrh gore, ki se mi je zdel komaj vatel visok v primerjavi z globino človeškega premišljevanja«. ${ }^{108}$ Gorniški vzpon je petrarkistična parabola življenja, ki po tesni poti (arcta via) vodi na visok hrib (celso loco). ${ }^{109}$ Predrugačena občutljivost renesančnega humanizma za intimno osamo ne pomeni umika v »divjo « izolacijo ali protisvetno samoto, temveč nasprotno obdelovanje socialne človečnosti, "povzdignjenje človeškega sveta, sveta vrednot, dejavnosti, jezika in družbe, ki povezuje onkraj časa in prostora, onkraj vseh meja . $^{1{ }^{10}} \mathrm{~V}$ tem duhu gre brati Salutatijevo razpravo De seculo et religione (O času in veri) iz leta 1381, posvečeno prijatelju Niccoloju iz Uzzana (1359-1431), ki je 23. februarja $1379 \mathrm{z}$ imenom Girolamo vstopil v kamaldulenski red uglednega florentinskega samostana Santa Maria degli Angeli. Salutati poziva k spoštovanju redovniškega stanu, a hkrati prijatelja spodbuja k delovanju. Na kratko, premisliti in uravnotežiti želi krščansko hierarhijo etičnih vrednot.

Uvid v tragičnost človeškega bivanja krepostnika ne potre, temveč prebuja v ustvarjalnem srcu človečnosti - v svobodni volji, edinem orodju, ki zmore parirati determinizmu usode. Polje civilnega odrešenja se iz starogrškega spoznavoslovja prevesi v krščansko družbeno etiko. Dostojanstvenik ne beži pred odgovornostjo do naravnega in družbenega stvarstva, kakor zapiše Salutati v pismu očetu Raffaellu di Guidu Boncianiju z dne 8. januarja 1402: ${ }^{111}$

103 Avguštin, Izpovedi 10.8.15; De vera religione 39.72; Ennaratio in psalmum 145.5.

104 Mark Avrelij, Dnevnik 4.3.

105 Glej Kalan, »Uvod«.

106 Petrarka, Familiares 4.1.29.

107 Ibid. 4.1.33.

108 Petrarka, „Vzpon na Mont Ventoux«, 114.

109 Ibid. 4.1.13.

110 Garin, L'umanesimo, 29.

111 Salutati, Epistolario 13.1, 3. del, 569-584. 
[V]elike so muke, a še večje zasluge: splača se hrepeneti po tem, da bi se ujeli v prepad boja, kajti najvišji mir dosežemo skozi vztrajno delovanje. Treba je stati na okopih, iti v ogenj in boriti se za pravico, za resnico, za iskrenost.

Moderno politično misel podpirata trdna humanistična stebra: voluntaristični optimizem ${ }^{112}$ in meščanski individualizem. Prvič: Salutatijeva teoretizacija svobodne volje za pol stoletja in več prehiteva renesančne hvalnice, kako je homo faber ipsius fortunae. ${ }^{113}$ Salutati je zgoden, a nikakor nezrel humanist. Dramatičnosti bivanjske vrženosti v svet ne zanika, nasprotno, ozavešča jo in premišlja ter ravno iz zavesti o najhujšem črpa navdih za napor, trud, udeležbo. Nepomirljivo eksistenčno napetost - živeti, trpeti, umreti - zgodnji humanisti investirajo v socialni angažma (impegno civile). Ostanejo zvesti zemlji in sprejmejo tostransko trpljenje zato, da bi bedo presegli $\mathrm{z}$ dostojanstvom. $\mathrm{Z}$ raziskovanjem in preizpraševanjem samih sebe zapuščajo varno področje determinizma, odkrivajoč svojo svobodo in obenem brezno, ki zija okrog nje. Z odkrivanjem človeške veličine se nagnejo nad prepad življenjske enigme. Mimo Herkulovih stebrov zaplujejo v južna morja možnosti in danosti, obljub in zanikanj, upanja in obupa. Življenje postane izziv, v katerem se s priložnostjo zmage poveča možnost poraza. Svoboda je predvsem tveganje in često breme. ${ }^{114}$

Salutati v poslednjem, dolgem in razvejanem ter nedokončanem pismu konservativnemu dominikancu Giovanniju Dominiciju (okr. 1356-1419), zapisanem pozimi leta $1406,{ }^{115}$ zagovarja primat svobodne volje na okopih civilno dejavnega življenja. Toda nikdar ne obljublja nemogočega. Usodo je mogoče premagati le v posamični bitki, v vojni nikdar. Problem humanistične svobode ni doseganje cilja, temveč hoja po poti: gre za to, da sprejmemo življenjske preizkušnje, se soočimo z eksistenčnimi izzivi in spopademo z viharji zemeljskega bivanja. Topos usode odpira »zelo občutljiva filozofsko-teološka vprašanja (volja, odgovornost, milost, predestinacija), ki bodo v nadaljevanju privedla do nepredvidljivih razvojnih nasledkov «. ${ }^{116}$ Sokrat ni humanistični seštejemo s ključnima kategorijama te dobe, voljo in razumom, dobimo dovolj natančen rezultat. Historični humanisti so pesimisti razuma in optimisti volje.

113 Mirandola, O človekovem dostojanstvu, 6-7.

114 Pellegrini, Umanesimo, 12.

115 Salutati, Epistolario 14.24, 4. del, 205-240.

116 Cappelli, L'umanesimo, 84-85. 
zgled zato, ker bi dosegel negativno svobodo, ${ }^{117}$ temveč zato, ker se je trudil svobodno živeti, celo za ceno izgube svobode in življenja samega. Salutati ne zaupa v emancipatorno vlogo svobodne volje zato, da bi bežal od Boga, temveč nasprotno, da bi skozi odgovarjanje klicu vesti, delovanje, našel prvega gibalca in sodnika - vero. Nihče se ne more odrešiti drugače kot po božji milosti. ${ }^{118}$ Toda politična zavest se je vendarle premaknila v smeri modernosti: Salutati je našel prostor politični odgovornosti in svobodni volji na račun teocentričnega determinizma. Človek si je izboril zemeljski prostor, ki mu pripada. Posameznikove vesti kot srčike emancipacije nista filozofsko in teološko izumila ne Luther ne Erazem: katoliški humanisti so stoletje pred reformatorji ozavestili posameznikovo (odgovorno) vlogo $\mathrm{v}$ družbi in pred Bogom.

Drugič. Humanistična smernica politične filozofije teče od posameznika, zasebnosti, k družbi, javnosti, torej sokratsko. ${ }^{119}$ Protoliberalni načeli družbene etike nista neskladni. Humanistične sanje krepostnega individualizma kot temelja socialno pravične družbe ostajajo neizpolnjene. ${ }^{120}$ Humanisti gradijo družbo z izhodišča posameznika. ${ }^{121}$

Salutati v delu De nobilitate legum et medicinae (O plemenitost $i$ prava in medicine, 1399) utemeljuje organicistično pojmovanje civilnega zdravja. Če medicina zdravi telo, politika zdravi (socialno) dušo - kakor civilna religija. ${ }^{122}$ Namen civilnega humanizma je utrditi, ne ošibiti, božjo moč na zemlji, za kar je bilo v času globokih vrednotnih transformacij treba uravnotežiti in uglasiti posvetno fabulo z razodeto resnico. Proces novoveške laizacije sveta požene krščansko motrenje vesti in vere, človeka in Boga. Civilno krščanstvo kliče k osebni skrbi za družbeno zdravje, ki je ravno v sodobni koronski normalnosti najbolj v nevarnosti.

V sebi premišljam o mističnem telesu, sestavljenem iz človeške množice, ki se združuje v družine, dežele, mesta, ljudstva, kraljestva in cesarstva; opazujem urejevalno moč zakonov, ki nad vsem kraljujejo in vse ohranjajo, ter se sprašujem, ali znanost, umetnost in delovanje zmorejo kaj več kot, če že, preprečiti telesne bolezni [...]. Resnično zdravje človeške družbe ni odvisno od medicine, temveč

117 Skinner, Virtù rinascimentali, 237-270.

118 Salutati, De fato et fortuna 2.10.

119 Platon, Apologija 31c-32a.

120 Pellegrini, Umanesimo.

121 Pellegrini, Religione e umanesimo, 223.

122 Pellegrini, Religione e umanesimo, 96. 
od duševne pogodbe med njenimi člani [...]. Nemogoče je oskrbeti vsa bitja, ki sestavljajo človeško združenje, torej ves človeški rod. Človeštvo se vzdržuje, nahrani in razcveta skozi zakone. Ta dobrina je tako obča, pa vendar tako božanska, bolj kot katerasižebodi posamičnost medicine. ${ }^{123}$

\section{PESIMISTIČNI OBRAZ RENESANSE}

Če se civilni humanizem kot ciceronska skladnost etike in politike začne s Salutatijem, doživi apoteozo in hkrati konec z Niccolojem Machiavellijem (1469-1527), ki politično tehniko loči od moralnih norm, ne pa tudi od etike. Za razumevanje prelomnega dela Il Principe (Vladar) je potrebno najprej upoštevati prej omenjeni pesimistični obraz, ne obrat, ki iz latentnosti vdira v najrazličnejše in nepričakovane oblike renesančnega humanizma kakor tragiški pečat refleksije o človeku. ${ }^{124} \mathrm{Na}$ svetu mrgoli nevarnosti, da je treba »zmeraj držati nož v rokah « ${ }^{125}$ saj so ljudje - če prosto naštevamo grešnike iz Vladarja - stiskači, grabežljivci, okrutneži, milosrčni, verolomneži, mehkužneži, bojazljivci, kruti, prevzetni, pohotni, lisjaki, lahkomiselni, frfre, neverni, hudodelci, zaničevalci in sovražniki, lizuni in prilizovalci, politika pa se odvija na »krivičnih dvorih ${ }^{126}$ Zgodovina je zanj, prej kot historia magistra vitae, ${ }^{127}$ zbirka ponavljajočih se človeških zmot, arhiv bolečih napak in vrtinec grešnih tegob, je negativ ujetosti človeka $\mathrm{v}$ cikličnost časa, $\mathrm{v}$ večno vračanje enakega. Ker je vse na svetu »tako spremenljivo «, ${ }^{128}$ je človeška zgodovina bolj kot napredujoči proces brezplodno, odvečno ciklično valovanje: vladarji, države, ljudstva in narodi se v vicovsko pretakajočem se obzorju zgodovine pojavljajo in izginjajo: »ker so namreč človeške reči v nenehnem gibanju, se bodisi dvigajo, bodisi gredo navzdol «, ${ }^{129}$ kakor zapiše v delu Discorsi sopra la prima Deca di Tito Livio (Razmišljanja ob prvih desetih knjigah Tita Livija). Človeška svetna izkušnja je razpeta med nespremenljivo (ergo nepopravljivo) človeško naravo in voljo po njenem spreminjanju, po

123 Poslovenitev odlomka iz dela De nobilitate legum et medicinae sledi sekundarnemu viru; Garin, I trattati morali di Coluccio Salutati, 24-25.

124 Ebgi, Umanisti italiani, 12.

125 Machiavelli, Vladar 8, 44.

126 Garin, La cultura, 94.

127 Ciceron, O govorniku 2.9.36.

128 Machiavelli, Vladar 10, 53.

129 Machiavelli, Politika in morala (Razmišljanja ob prvih desetih knjigah Tita Livija 2.1), 146. 
krojenju in pisanju zgodovine. V zgodovini je stalno le to, da ni nič stalnega. Neskončna prilagodljivost človeka vse spreminja zato, da bi se nič ne spremenilo. ${ }^{130} \gg$ C̆as namreč potiska pred sabo vse mogoče in lahko prinese s sabo dobro in slabo, slabo in dobro. $\ll^{131}$

In ko razmišljam, kako vse to poteka, sodim, da je bil svet zmeraj na enak način in da je bilo na njem toliko dobrega kolikor slabega, toda to slabo in to dobro se od dežele do dežele spreminja: to je očitno iz tistega, kar vemo o starodavnih kraljestvih, ki so se zaradi spreminjanja navad razlikovala drugo od drugega, toda svet je ostal isti ... ${ }^{132}$

Prenovitveni načrti se v pozni renesansi posvétijo in prenesejo iz osebne ravni dušnega odrešenja na laično raven družbenega osvobajanja. Niccolò Machiavelli, Florentinec po rodu in pripadnosti, je večinoma deloval - izgnan, odtujen in zagrenjen - izven rodnega mesta na družinskem posestvu vile Albergaccio v trgu San Casciano, kjer je med julijem in decembrom ${ }^{133} \mathrm{v}$ črni jeseni ${ }^{134}$ leta 1513 nastala tudi življenjska mojstrovina, postumno objavljeno in Lorenzu posvečeno delo Il Principe, »jasen, sistematičen in skoraj suhoparno racionalen spis, ki opisuje oblike oblasti in tehnologijo vladanja v manjši državni tvorbi, ne da bi se pri tem kakorkoli oziral na moralna načela «. ${ }^{135}$ Gre za prvo znanstveno ${ }^{136}$ delo, ki historično ločuje področje politične tehnologije od moralnih in drugih determinant, ${ }^{137}$ tako da racionalno analizira tehnično-praktična vprašanja politične oblasti. ${ }^{1{ }^{8}}$ Avtonomizacija politike predstavlja odločilen epistemološki in metodološki prelom za moderno zgodovino idej. Politiko (in politike) smemo odtlej obravnavati super partes, s ptičje perspektive, »kajti kakor se tisti, ki slikajo pokrajine, postavijo kam v dolino, da gledajo goré in hribe, a se povzpnejo visoko v hribe, da gledajo ravni, prav tako je

130 Transformizem ali, v italijanskem kulturnem miljeju, gepardizem, po junaku iz romana Giuseppeja Tomasija iz Lampeduse Il Gattopardo (Gepard).

131 Machiavelli, Vladar 3, 17.

132 Machiavelli, Politika in morala (Razmišljanja ob prvih desetih knjigah Tita Livija 2.1), 146.

133 Garin, La cultura, 93.

134 Škamperle, »Tehnologija oblasti«, 128.

135 Ibid..

136 Garin, La cultura, 97.

137 Škamperle, »Tehnologija oblasti«, 129.

138 Garin, La cultura, 94. 
potrebno biti vladar, da dobro spoznaš naravo ljudstev, in človek iz ljudstva, da dobro spoznaš čut vladarjev. «139

Machiavellija prej kot državne oblike, način prevzemanja in ohranitve oblasti, vojaške zadeve ali državne teorije zanima figura politika kot genija individualnosti, ki se je po družbeni lestvi dvignil "po svoji sposobnosti, ne po sreči«. ${ }^{140}$ Dober politik ni »dober « državljan, temveč sposoben in uspešen, močan in pogumen, odločen in učinkovit razumnik, ${ }^{141}$ kasneje bi rekli razsvetljeni suveren, nekakšen državniški znanstvenik $\mathrm{z}$ močnimi vodstvenimi sposobnostmi »kdor tu ne bo pametno krmaril, bo prav kmalu izgubil, kar si je prisvojil «. ${ }^{142}$ Vladar, četudi čezetični junak, je prvak etike vrlin, saj lahko drugim dobro gospodari le tisti, ki zna najprej zagospodariti sebi: »oni, ki je lahko najbolje urejen za vladanje, [je] zmožen najbolje urediti druge. ${ }^{143}$ Učbeniško gre za prvo poglavje moderne sekularizacije, ki državne zadeve ločuje od religiozne morale, politiko od cerkvene etike, pa vendar nova politična tehnologija oblasti nikakor ni brezetična, kajti razvije svojo, notranje samostojno etičnost. Kar se določanja smotrov in ciljev vladanja tiče, nad vsemi kraljujeta blaginja državljanov in državna suverenost. Pragmatične kriterije vladanja je mogoče vrednotiti izključno na podlagi meril koristi in uspešnosti. Politična tehtnica preverja, ali je vladar s svojimi odločitvami sodržavljanom prinesel blaginjo in ali je ohranil politično avtonomijo mestne države. Dober vladar ni moralist, ne puritanec, omikanec, prijaznež ali obzirnež s pravičnimi načeli, temveč uspešen oblastnik, knez ali monarh, ki zasleduje državne cilje »za vsako ceno«, kar je pravi filozofski problem makiavelizma. Politik je izurjen in izkušen lokostrelec, ${ }^{144}$ ki zadeva v črno zato, ker muho naravnava dovolj visoko, ne zaradi pohlepa ali karierizma, temveč zato, ker je tukaj in zdaj mogoče koristiti le, če ciljaš naprej in navzgor. Vsaka krepostna politika, tudi tista, ki se otepa moralnih determinant, je torej gesta človeškosti in v tem antropološkem jedru etična. ${ }^{145}$

139 Machiavelli, Vladar Predgovor, 7.

140 Ibid. 6, 27.

141 Ljudi razločujemo po treh vrstah pameti (tre categorie di cervelli): "prva razume vse sama, druga dojame, kar razume kdo drug, tretja pa ne razume ne sebe ne drugih - prva je izvrstna, druga dobra, tretja odveč« (Machiavelli, Vladar 22, 103).

142 Machiavelli, Vladar 3, 15.

143 Dante, Monarhija 1.13.

144 Machiavelli, Vladar 6, 27.

145 Havel, »Politika in vest«, 30. 
V simbolno najmočnejšem odlomku Vladarja Machiavelli primerja moč zakona in sile (pravo in vojsko) s človekom in zverjo. Politika je »umazana igra", ki od dobrega vladarja zahteva, da si v imenu skupnosti »umaže roke« $\mathrm{z}$ zverinskim, da kakor lev na robu človeških zakonitosti kroti živalske sile, da torej »zna rabiti prvo in drugo naravo, ker ena brez druge ni obstojna «. ${ }^{146}$ Med volkovi preživi le, kdor zna tudi gristi, kdor je pripravljen sklepati kompromise. Vladar se mora soočiti z nedobrim, če hoče, da privre dobro na dan. ${ }^{147}$ Machiavelli obrne na glavo razmerje med dobrim in slabim, krepostjo in grehom, resnico in lažjo: „Če namreč vse dobro pretehtamo, ugotovimo, da ga [vladarja] marsikaj, kar je videti krepost, če se ravna po njej, pripelje v pogubo, marsikaj drugega, kar je videti napaka, pa mu prinese varnost in blaginjo. ${ }^{148}$ Dobro se le trudoma najde, zlo pa je vedno na preži za vogalom. ${ }^{149}$ Moralne vrednote izgubijo vsakršno bitno, substancialno resničnost in se odslej osmišljajo le relacijsko, odvisne so od smotra in učinka, toliko, da je mogoče celo hudodelstvo in okrutnost dobro uporabiti. ${ }^{150}$ Malo zlo torej lahko opraviči veliko dobro, videz dobrote, laž, pa resnično dobro. ${ }^{151}$ Machiavellijev Vladar, Albertijev Momus, Morova Utopija in Erazmova Hvalnica so sadeži poznorenesančne odčaranosti, ki bedi navkljub verjame in upa v človeškost.

Politik kot umetnik državnosti izzove usodo na dvoboj, v katerem zmaga le eden: »človek je tisti, ki mora s svojo razumnostjo in odločanjem ne le predvideti, temveč z lastno močjo nadvladati [usodo] in iz nje narediti triumf svobode $«{ }^{152}$ Kakor Salutati tudi Machiavelli ne trdi, da bi zmogla volja nadvladati usodo, temveč ji mora odžreti nekaj življenjskega prostora. Usoda je kot deroča reka, na katero se moramo $\mathrm{v}$ mirnih časih pripraviti $\mathrm{z}$ nasipi in bregovi:

146 Machiavelli, Vladar 18, 8 o.

147 Ibid. 15, 71 .

148 Ibid. $15,72$.

149 Takole Demokrit: »Tisti, ki iščejo dobre (stvari), jih le stežka najdejo, medtem ko (jih) slabe (doletijo) tudi, če jih ne iščejo.« (Diels in Kranz, Fragmenti predsokratikov, frg. 68 в 108, 2.907.) Zgodnji humanizem prevzema antično nravstveno pravilo zlate srednje mere, aurea mediocritas, kot ji Horacij pravi v Odah (Carmina 2.10.5) ali v Satirah, kjer zapiše pregovorni Est modus in rebus (Satirae 1.1.106-107). Teorija zmernosti sega nazaj do predsokratikov, če vztrajamo z Demokritom, prim. frg. 68 в 191 in 68 в 233: „Tistemu, ki prekorači (pravo) mero, najprijetnejše (stvari) postanejo najbolj neprijetne.« (Diels in Kranz, Fragmenti predsokratikov, 2.945.)

150 Ibid. 8, 44.

151 Machiavelli, Vladar 19, 82.

152 Garin, La cultura, 96. 
Ni mi neznano, kako so mnogi menili in menijo, da stvari tega sveta vodita usoda in Bog, in sicer tako, da jih ljudje s svojo sprevidevnostjo ne morejo popraviti, še več, da zanje sploh ni pomoči. [...] Da pa docela ne odpravimo svobodne volje, vendarle sodim, kako bi utegnilo biti res, da je usoda razsodnica polovice naših dejanj in da drugo polovico ali približno toliko prepušča v odločanje nam samim. Primerjam jo eni tistih deročih rek, ki tedaj, ko se razbesne, poplavljajo doline, podirajo drevesa in rušijo hiše, tu odnašajo zemljo, tam jo naplavljajo; vse beži pred njo, vsi se umikajo njenemu navalu, ne da bi se mu mogli kje ustaviti. Čeprav so takšne, nikakor ne pomeni, da ljudje, kadar so časi mirni, ne morejo ničesar ukreniti proti njim, graditi brani in nasipe, da tedaj, ko spet narastejo, bodisi odteko po kanalu bodisi njihovo divjanje ni ne tako neobrzdano in ne tako škodljivo. Podobno je z usodo, ki pokaže svojo moč, kjer ne naleti na odpor, in usmerja svoj divji tok tja, kjer ve, da ni nasipov in brani, ki bi jo zadržale. ${ }^{153}$

Politik je torej družbeni zdravnik, če naj se izrazimo salutatijevsko, ki skupnostno telo zdravi s preventivnimi ukrepi. Socialne bolezni lahko predvidi samo, kdor se spozna na »svojo « družbo, zato smemo trditi, da je edina prava politična odločitev sprejeta preventivno, $\mathrm{v}$ "mirnih«, ne v kriznih časih. Ko nastopijo simptomi socialnega telesa, je pogosto že prepozno. „Če namreč misliš nanje, ko so daleč, jim zlahka odpomoreš; če pa čakaš, da pridejo bliže, je prekasno za zdravilo, kajti bolezen je postala neozdravljiva. [...] Spričo tega so Rimljani, ki so nevšečnosti videli že daleč vnaprej, zmeraj našli zdravilo. «154

Kopernikanski obrat je pred vrati: človek izgublja središčno vlogo $\mathrm{v}$ kozmološkem in fizikalnem, pa tudi v moralnem smislu. Machiavelli razume in ubesedi »etično-politične posledice nepovratne krize srednjeveškega sveta «, ${ }^{155}$ propadanje tisočletnega idejno-vrednotnega reda, za današnje razmere nepredstavljivo izpraznitev dotedanjih referenčnih meril aplicira na znanstveno analizo vladarske vloge $\mathrm{v}$ kontekstu mestnih državic. Saj že Garin opozarja: »Bolj kot za spor med etiko in politiko, med religijo in politiko, Machiavelli zagovarja trditev, da je temelj in smoter delovanja skupnostnega človeka ohranitev in razvoj res publica« ${ }^{156}$ Proti izvotljeni prepojenosti politike s teocentrizmom žanje setev zgodnjih humanistov $\mathrm{z}$ razvitjem laične

153 Machiavelli, Vladar 25, 109.

154 Ibid. 3, 16. Avtor misli na sifilis.

155 Garin, La cultura, 99.

156 Ibid., 96. 
in liberalne antropologije. Za »humanista Machiavellija je odločilen vladar, ne vladavina, posameznik, ne ustanova, kakor "gospodič, bojevnik, povzpetnik ali vladar, ki naj bi izkazoval zaničevanje do srednjeveškega pojmovanja krščanske družbe in zavračal njeno hierarhično ureditev, ki sta jo zaznamovala oba meča tradicionalne delitve najvišje oblasti, papeštva in cesarstva«. ${ }^{157}$ Machiavellijeva država je resnično, ne idealno mesto, je dejanskost, ne utopičnost, je delovanje in ne kontemplacija. Machiavelli je cvetober aristotelske, ne platonske etike, in v tem smislu nadaljuje - bolj kot pa prekinja živec zgodnjehumanističnega dobrega delovanja.

\section{NOVOPLATONISTIČNO POJMOVANJE LJUBEZNI PRI MARSILIU FICINU}

Marsilio Ficino (1433-1499) je bil ob Nikolaju Kuzanskem (1401-1464) nedvomno najpomembnejši filozofski mislec zgodnje renesanse in ob velikem intelektualnem in filološkem delu humanistov zaslužen za menjavo paradigmatskega polja mišljenja, ki smo mu priče na prehodu iz pozne sholastike v nastajajoči novi vek. Med njima zaradi starostne razlike ni bilo neposrednih stikov, niti ne razvidnega idejnega vpliva. Kljub temu imata filozofiji obeh avtorjev tesne, pomembne notranje vezi in kakor so pokazali poznavalci njune misli, npr. Ernst Cassirer v delu Individuum in kozmos v filozofiji renesanse, ${ }^{158}$ skupaj zaznamujeta ter vsak po svoje sooblikujeta temeljni prehod evropske kulture in mišljenja iz srednjega v novi vek. Ni šlo le za problem spoznanja, pri katerem je imel Kuzanski nedvomno temeljno vlogo, niti ne za moralne spise in filološko kritiko humanistov, ki so spremenili intelektualno polje razprav; z njima je za novi vek pomembno spremembo doživelo sámo pojmovanje metafizike, s tem pa tudi razumevanje religije. Spreminjal se je način razumevanja Boga, sveta in človeka v svojem zgodovinskem in družbenem prostoru, pri teh vprašanjih, ki jih na kratko lahko povzamemo z oznakami ponotranjene duhovnosti in rojevanjem subjektivne zavesti, je imel Florentinec Marsilio Ficino pomembno vlogo. Če je Kuzanski, kakor je to dobro videl Cassirer, razlago in opravičenje sveta iskal v pojmovnih shemah, matematiki in kozmologiji, sta Ficino in Platonova Akademija za razumevanje sveta in človeka $\mathrm{v}$ ospredje postavljala dušo in lepoto.

Ficinovska teodiceja, če smemo tako reči, je vsa povzeta v lepoti stvarstva, ki je dokaz za božanski izvor sveta in jo strnjeno povzema 
človeška moč ljubezni. Ta namreč nastopa kot osnovna motivacija v sklenjenem krogu človeške duše, razpetem od božjega izvora, ki ostaja človeku racionalno nespoznaten, temelji pa v dobrem, ki ga v svetu manifestira lepota oblik, do vračanja k izvoru. Temeljni nagib celotnega loka človeške eksistence je v resnici ljubezen. To ne drži le za človeka, ampak za vsa bitja vesolja, le da to ljubezen vsakdo pozna in jo izraža na način, ki je primeren njegovi naravi. Preko nagiba ljubezni, ki ga na svoji ravni bivanja izražajo vsa bitja vesolja, od rastlin do zvezd, se v svojem ljubezenskem nagibu k izvoru ozira tudi človek, ki se s pomočjo ljubezni dvigne nad snovno realnost, $v$ želji, da bi se spojil z večnim in božanskim; z izvorom svoje biti in končnim ciljem. $\mathrm{Ob}$ tehtnem razmisleku pa se pokaže, da tema ljubezni, kot jo v svojem spisu O ljubezni razgrinja Ficino, ni tako oddaljena ali tuja sodobnim pogledom, kot si morda mislimo. Pri tem je Ficino naslednik duhovne usmeritve, ki je poglabljala brazdo intimne osebne oblike za dojemanje Boga in resnice, ki jo je zahodnemu človeku nakazal sveti Avguštin v pozni antiki, v poznem srednjem veku pa je to usmeritev s hvalnico Platonu poudaril Petrarka. V svojih Pismih domačim (Familiares) je sicer potožil, da sam ne zna grško, zato Platon, v katerem je slutil visoko modrost, zanj žal ostaja nem. Ficino pa se za razliko od Avguština ne ozira več v apriorno zaupanje v božjo milost, ampak razume človeka kot tistega, ki ima možnost in nalogo samostojnega odločanja. V tem smislu imamo lahko Ficina za enega osrednjih mislecev renesanse, obdobja, ki je predrugačilo človekove načine bivanja in razumevanja sveta, sebe in resnice.

Marsilio Ficino je bil v tem kontekstu zaslužen predvsem za obuditev novega platonizma, čeprav ne toliko v zgodovinsko kritični in filološki obliki kakor v pomenu razkritja platonskih misterijev, v spoštljivem pristopu do modrosti, ki naj bi posredovala večne resnice duha in sveta, kakršne so stari modreci pred neukim ljudstvom raje zakrili v simbolne podobe in bajeslovne prilike. Hkrati si je Ficino zamislil velikopotezen načrt, ki ga je deloma tudi izpeljal - povezati antični platonizem s krščanstvom, pokazati na globinsko skladnost obeh nazorov in njuno ujemanje.

Ficinov prevodni opus je sam po sebi vreden spoštovanja, že zaradi njega nastopa kot ena osrednjih intelektualnih figur v širšem renesančnem obzorju. Prvi je v celoti v latinščino prevedel Platonove spise (natis leta 1484), med katerimi je nekatere opremil z obsežnim komentarjem (Parmenid, Timaj, Menon), komentar k Simpoziju pa se je prelevil v pravi samostojni traktat o ljubezni. Prva verzija, napisana v latinščini, Commentarium in Convivium Platonis de Amore, ki jo je sam podpisal in se je ohranila (Vat. lat. 7705 ms.), nosi datum Anno 
1469, mense Iulii. V tiskani obliki je izšla skupaj s Platonovimi zbranimi deli (1484). Kmalu nato je Ficino poskrbel, kakor še za nekatere druge svoje spise (De christiana religione, De raptu Pauli; tudi za svoja Pisma ter za prevod hermetičnega Corpusa), za prepis v tedanji toskanski ljudski jezik, italijanščino. Njegov spis O ljubezni (De amore) je močno vplival na literaturo in liriko v 16. stoletju, v Franciji in širše po Evropi. ${ }^{159}$

Ob Platonu je Ficino v latinščino prestavil vrsto drugih novoplatonskih filozofskih spisov, med katerimi sodijo v sam vrh Plotinove Eneade, ki še poglabljajo duhovni horizont platonizma in so, podobno kot Platon, s Ficinom sploh prvič celostno vstopile v zahodni duhovni svet in s platonizmom navdihovale izobražence vse do obdobja romantike in moderne. Kant in Goethe sta brala Platona v Ficinovem prevodu. Zvrstili so se prevodi mnogih drugih avtorjev, že omenjeni Corpus hermeticum, pripisan legendarnemu egipčanskemu modrecu Hermesu Trismegistu, Orfejeve himne, kaldejski oraklji, pitagorejski Zlati verzi in vrsta drugih tekstov. Ves ta zajeten prevodni opus, opremljen s komentarji, nastopa v posebnem duhovnem kontekstu, ki je v resnici prava oznaka Marsilia Ficina in njegove misli. Ne gre le za literarnozgodovinsko in spoznavno filozofsko pridobitev, s katero si renesansa prisvaja pomembno dediščino in skuša na njej zgraditi lastno istovetnost, ampak za precej več kot to. Ficino je to modrostno izročilo razumel kot izvirno modrost (prisca theologia), s katero se je bila že v davni dobi izrazila božanska resnica, ki je v ohranjenem izročilu dosegla svoj vrh s Platonom, svojo dopolnitev pa z božjim učlovečenjem v Jezusu Kristusu. Predplatonska duhovna izročila in sam Platon so v Ficinovih očeh pridobili preroški značaj, ker se v globini ujemajo s starozavezno Biblijo in ponekod še jasneje kot slednja napovedujejo rojstvo božjega Sina. Ficino je na ta način skušal postaviti na noge povsem novo apologijo, ki naj bi v dobi splošne družbene in religiozne krize, predvsem njene politično institucionalne ravni, krščanstvu vrnila moč pristnega razodetja in mu omogočila novo relevantnost. Sam je verjel, da je božje razodetje večno prisotna duhovna realnost, zato lahko upravičeno sledimo izrazom te resnice že pred samim Kristusom. ${ }^{160}$ Do tega izročila Ficino ni nastopal kot objektivni filolog ali nevtralno zadržani filozof, ampak kot vernik pred izviri notranje luči, ki jo v vseh časih daruje Bog. Filozofija sama naj

160 Dober pregled novoplatonske tradicije, ki jo v Ficinovem pomenu lahko beremo kot duhovno naprezanje človeka in njegove filozofije v smeri razodevanja božjega Logosa in misterija njegovega učlovečenja, je podal Andrew Louth v delu Izvori krščanskega mističnega izročila. 
bi bila po njegovem božji dar. Pri svojem delu si je vselej prizadeval pokazati, kako sta si filozofsko spoznanje in religiozna zavest v globini sorodna ali kar komplementarna, le da moramo znati prisluhniti tisti pravi pobožni filozofiji (pia philosophia) in si na drugi strani prizadevati za učeno religijo (docta religio).

Ficinovo filozofsko ustvarjanje, njegova duhovna pot in nasploh vpliv, ki ga je zapustil italijanski in evropski kulturi v dobi renesanse, pa tudi globlje v novi vek, saj so njegovi odmevi segli vse do oživljenega zanimanja za duhovno mistiko in ezoterična izročila proti koncu 19. stoletja, so bili deležni precejšnje študijske pozornosti. V novejšem obdobju so Ficina in njegova dela preučevali predvsem trije avtorji, švicarski literarni kritik Raymond Marcel, ki je poskrbel za moderne - a danes že presežene - izdaje nekaterih njegovih del; zgodovinar filozofije Eugenio Garin s svojimi očarljivo napisanimi študijami o humanistični kulturi tistega časa in nepozabnimi eseji o Ficinu, Picu, Albertiju in drugih; ${ }^{161}$ ter nemško-ameriški raziskovalec Paul Oscar Kristeller, ki se je posvečal študiju kulture in filozofije v obdobju renesanse ter še posebej delom Marsilia Ficina.

Garin pravi, da je bil Ficinov vpliv izjemen, ne le za literarno in filozofsko kulturo 15. in 16. stoletja, ko je bil med najodmevnejšimi spisi, posebno v Franciji, prav njegov komentar o ljubezni. Ta vpliv nastopa večinoma zabrisano in $\mathrm{v}$ neizrečenih oblikah, bolj implicitno kakor evidentno določljivo; toda ko gre za mnogotere odtenke duševne ponotranjenosti, ki je postala ena od značilnosti duhovne drže evropskega človeka, njegovega razumevanja religije in ne nazadnje resnice sveta in človeka, v brazdi, ki so jo po Platonovih sledeh pomembno skopali Avguštin, Petrarka, v novem veku pa Pascal, Rousseau, Kierkegaard, moderni eksistencialisti in mnogi drugi, ostaja vpliv Ficina tako rekoč neizmerljiv. Garin piše, da skorajda ni duhovne teme v evropski kulturi, kjer ne bi našli njegovega odmeva.

Od sredine šestdesetih pa tja do začetka devetdesetih let 15. stoletja se razgrinja Ficinovo zrelo in najbolj ustvarjalno obdobje. Kljub vedno prisotni negotovosti in občasnih nemirih tako na družbeni ravni kakor v osebnem življenju (zarota družine Pazzi proti Medičejcem leta 1478; krajša epidemija kuge) je bilo to za florentinsko renesanso obdobje relativnega miru. Leta 1484 so v tiskani obliki izšli Platonovi dialogi. Nasploh naj bi šlo, nekateri so trdili, da zaradi konjunkcije Saturna in Jupitra novembra tega leta, za posebno leto, annus mirabilis. ${ }^{162}$

162 Na to se navezuje Ioan P. Couliano v zanimivem delu, v katerem se posveča teoriji imaginacije in definiranju "pnevmatičnih vezi«, kar ustreza sodobnim 
Poleg prevodov drugih novoplatonskih del iz pozne antike je Ficino leta 1468 , torej leto pred latinsko verzijo spisa O ljubezni, prevedel iz latinščine v ljudski jezik tudi Dantejevo Monarhijo. V tem obdobju je Ficino napisal svoja poglavitna izvirna dela. Leta 1474 je končal najobsežnejše izvirno delo, Theologia platonica sive de immortalitate animorum (Platonska teologija ali o nesmrtnosti duš). Gre za obsežno delo, razdeljeno na $18 \mathrm{knjig}$ in posvečeno Lorenzu Veličastnemu. Delo se loteva $\mathrm{v}$ renesansi živo občutene in široko filozofsko obdelane teme nesmrtnosti duše. Na filozofski osnovi, bodisi po tomistični poti, opiraje se na Aristotela, oziroma po navdihu Platona in platonizma, kakor Ficino, ki naslov dela povzema od Prokla, so filozofi in teologi skušali pokazati na razumnost in zanesljivost verovanja v nesmrtnost človeške duše. To naj bi potrdilo osnovno resnico krščanske vere. Nekateri, kakor Pietro Pomponazzi, pa so na sledi dveh »zgrešenih « interpretacij Aristotela, Aleksandra iz Afrodizijade in arabskega misleca Averoesa, ki je bil na univerzi v Padovi v poznem srednjem veku in renesansi zelo čislan, odkrito trdili, da je človekova duša umrljiva in da odmre skupaj s telesom, človekov um pa ob smrti zgubi svojo individualnost in se spoji s kozmičnim ali božanskim umom, toda brez osebne istovetnosti. Zaradi tega je bila Ficinova pojmovna skrb to, kako bi prišel do potrditve substancialne pluralnosti individualnih duš. S tem bi bila dejansko potrjena in rešena človekova osebna religiozno-metafizična utemeljitev.

Duša kot princip živosti in notranja oblika bitja ima v filozofiji Ficina osrednje mesto. Pri tem je pojem duše, ki je bil v novoveški filozofiji, posebno pa v moderni humanistični misli na splošno razvrednoten in ne nastopa $\mathrm{v}$ relevantnih teorijah, prikazan $\mathrm{v}$ poudarjeno novi, zelo originalni in - glede na srednji vek - moderni obliki. Duša je pojmovana kot živo jedro človeka, ki podobno kot v misli Nikolaja Kuzanskega ni odvisna od »zunanjih" posegov, naj gre za božjo milost ali za naravne vplive iz okolja (v tem okviru so mišljeni tudi astralni vplivi), ampak je sama žarišče gibanja, odločanja in delovanja.

teorijam transferja in upravljanju s psihološkimi vplivi med ljudmi in v družbi. Avtorja, ki ju romunski pisec postavlja v vrh renesančne teorije imaginacije, pa sta Ficino in Giordano Bruno; glej Couliano, Eros et Magie à la Renaissance. Couliano je bil učenec religiologa Eliadeja. Prevzel je njegovo dediščino in razvijal študij religij v psihološki smeri, v čemer je videl prispevek renesanse in njenih na videz nerelevantnih spekulacij. Prevzel je mesto profesorja na Divinity School v Chicagu (kjer je pred njim učil Eliade), vendar je bil maja 1991 na hodnikih študentskega kolidža skrivnostno ubit. Kdo je bil morilec in načrtovalec tega umora, do danes ni jasno; o tem Ted Anton, Eros, Magic, and the Murder of Professor Culianu (1996). 
Platonizem je lahko nekoliko sanjav - in takšna je tudi filozofija Marsilia Ficina. Njegovo delo nedvomno označuje prehod, ki ga preučevalci renesanse radi izpostavijo, to je prehod iz prve polovice quattrocenta, ko se je v zgodnjem humanizmu spreminjala forma komentarjev, vsebinsko pa so bila v ospredju konkretna moralna vprašanja, civilno življenje, zgodovinska refleksija in človekove ustvarjalne sposobnosti, ki so v veliki meri odvisne od jezikovnega znanja, vrlin in ne nazadnje od politične skupnosti - v drugo polovico stoletja, ko v ospredje spet stopijo živo občutene religiozne teme, družbena skepsa, namesto civilnega naprezanja pa pogosto ostro izražene apokaliptične vizije, naj gre za patra Savonarolo ali za hiliastično navdihnjene reformatorje. Njihove ideje so bile sicer povsem nasprotne, pogosto pa le korak oddaljene od jedke in cinične presoje kakega Machiavellija.

V tem obdobju, takoj po Platonski teologiji, je Ficino napisal dve pomembni religiozni deli, leta 1475 De christiana religione, ki jo je naslednje leto sam prestavil v ljudski jezik, ter spis De raptu Pauli (1476). Ficino je v svojem času dejansko nastopil v vlogi pretanjenega in v idejah zelo modernega apologeta krščanstva, ki se jasno razlikuje od srednjeveških meditacij in razprav, kot tudi od moralističnega pridiganja in zanosa dominikanskega patra Savonarole, s katerim se je dejansko sklenila novoplatonska avantura florentinske Akademije. ${ }^{163}$

Ficino je v svojem zagovoru krščanstva nastopil kritično tako do pesniških in zbadljivih prigodnic, kot so bile Poggiove Facetiae (anekdote iz rimskega kurialnega življenja) ${ }^{164}$ pa kritike Pulcija, in Valle, kakor do filozofskih smeri, ki so izhajale iz Aristotela, še posebno, če je šlo za Aleksandrovo ali Averoesovo usmeritev. Nov pa je bil predvsem način iskanja. Ficino je menil, da aristotelska usmeritev izničuje individualnost, ki je za človeka pomembna. Kljub hvalnici spoznanja Aristotel ne daje pravega odgovora na človekovo upanje. Srednjeveške tomistične sinteze niso zadovoljile novih in vse jasneje

163 Ficinovi pojmi univerzalne harmonije, soodvisnosti vseh bitij stvarstva, lepote in ljubezni, ki delujeta kot osnovno duševno vezivo in nagib, ki snovno naravo povezuje $z$ idejno in duhovno, ter koncept enega, skupnega in razvijajočega se razodetja božanske resnice, ki nastopa zgodovinsko in povezuje civilizacije, so kljub iskreni in veliki krščanski pobožnosti ostali nemočni pred pridigami in zanosom, s katerimi je v devetdesetih letih 15. stoletja v Firencah nastopil Girolamo Savonarola. Glej njegov spis Triumphus crucis (1497).

164 Kot je ugotovil Primož Simoniti, si je prvi škof novoustanovljene škofije v Ljubljani Žiga Lamberg dal prenesti v svojo poletno rezidenco v Gornji Grad med juridičnimi in drugimi rokopisi in redkimi tiski tudi ta spis, ki je očitno sodil v takratno literarno modo. Glej Simoniti, Humanizem na Slovenskem, 52, in Škamperle, Magična renesansa, 67, op. 31. 
izraženih potreb po razumevanju in vrednotenju posamezne osebe. Ficino je želel dvigniti na metafizično raven, vsaj ko gre za njeno bitno utemeljitev, človekovo osebno izjemnost in edinstvenost. Prav to je tudi implicitni zastavek njegovega spisa O ljubezni. V tem sta si Ficinov filozofski pogled na ljubezen in pojem človekovega dostojanstva, kot so ga razumeli humanisti generacijo pred njim, denimo Salutati in Manetti, zelo blizu.

Razmerje med vero in znanostjo, ki ga je Kuzanski skušal razrešiti po poti filozofije, na ravni spekulacije, sta Ficino in ob njem Pico della Mirandola, ki je v ta okvir vpeljal metodo kabale (Heptaplus, sedmerna pripoved prvih šestih dni stvarjenja), skušala razrešiti s principom razodetja. »Moderni« koncept religije, ki so ga nakazovala humanistična dela v prvi polovici 15. stoletja, vse od Salutatija naprej, se v drugi polovici in ob koncu 15. stoletja, v kontekstu večje družbene skepse in makiavelizma, ni izgubil. Novi pojmi religiozne zavesti, ki jih je Ficino razvil v spisu $O$ krščanski religiji, govorijo v duhu in s poudarki, ki nakazujejo versko reformacijo, vendar gre dejansko za moderen pogled na religijo: vera ni posledica »zunanjega « posega, ampak osebne odločitve in duha človeka. Odrešenje, ki ga človek pričakuje $\mathrm{s}$ celoto svojega bitja, $\mathrm{z}$ dušo in telesom, kot avtonomno bitje, ki je v neposrednem stiku z Bogom, pa spremeni pogled na celoten svet. Fizična narava ni »zavržena«, prav tako ni ovira v procesu dvigovanja k božanskemu, ampak je sama manifestacija lepote, ki se nam predaja kot vidni in čutni izraz metafizičnega principa absolutne biti. Pojem ljubezni je prav na tej osnovi lahko dobil povsem nove poudarke in oblike razumevanja, na katere so odločilno vlivali tako humanizem kakor novi pojmi filozofskega umevanja.

\section{ZAKLJUČEK}

Je Salutati makiavelist ali Machiavelli salutatijevec? Prej drugo kot prvo. Makiavelijevski politik zasleduje etični smoter, četudi za ceno neetičnih sredstev, ker je politika vedno upravljanje s kompromisi, mazanje rok, tveganje zla. Machiavellijev Vladar je Rubikon moderne politične teorije, prelomnica, ki "pokoplje en svet in drugega napoveduje ${ }^{165}$ Renesančna duhovna in miselna prenova je politično filozofijo v slabih dveh stoletjih turbulentno, pa vendar srečno prepeljala skozi Scilo in Karibdo antropološkega vprašanja. Začetek in konec se medsebojno podpirata in brišeta. Če sprejmemo, da je človek artifex svoje sreče, moramo hkrati priznati, da je lahko vir 
svoje nesreče. Politična misel renesanse niha med jajcem in jabolkom Salutatija in Machiavellija, med njunim optimizmom in pesimizmom, med nebom in breznom. Obe, tako utopičnost zgodnjih humanistov ko protiutopičnost poznih renesančnikov, sta povsod in nikjer, kot dva nasprotna si cardines, okrog katerih se suče srčika renesančne antropologije, vprašanje resničnega in idealnega mesta ali, če naj zaključimo komarjevsko, z odpirajočim zaključkom, nesklenjene in nesklenljive dvojnosti človeškega bivanja: idealnost in resničnost, vera in razum, upanje in resnica, svetloba in tema, protislovnost in ambivalentnost kreposti in grešnosti. "Na točki najostrejšega in najgrenkejšega občutja razdvojenosti in nemirnosti človeške družbe se potreba po miroljubnem in spokojnem mestu oživi in okrepi. Čeprav iluzija zgodnjih humanistov po možni skladnosti obeh mest, resničnega in idealnega, premine, še ne pomeni, da se resničnost enega ne sklicuje več na idealnost drugega. ॥ $^{166}$ 


\section{BIBLIOGRAFIJA}

\section{HISTORIČNI VIRI}

Alighieri, Dante. Božanska komedija: Raj, Vice in Pekel. Prevod Andrej Capuder. Celje: Mohorjeva družba, 2005.

—. Monarhija. Prevod Tomaž Jurca. Ljubljana: Slovenska matica, 2013.

Aristotel. Nikomahova etika. Prevod Kajetan Gantar. Ljubljana: Slovenska matica, 2002.

Avguštin, Avrelij. Izpovedi. Prevod Anton Sovrè. Celje: Mohorjeva družba, 1984.

Avrelij, Mark Antonin. Dnevnik cesarja Marka Avrelija. Ljubljana: Slovenska matica, 1988.

Ciceron, Mark Tulij. »O državi: Uvod«. Prevod Matej Petrič. Keria: studia Latina et Graeca 19, št. 2 (2017): 191-198.

Diels, Hermann in Kranz, Walther. Fragmenti predsokratikov. Prevod Dašo Benko et al., ur. Gorazd Kocijančič. Ljubljana: Študentska založba, 2012.

Ficino, Marsilio. El libro dell'amore. Ur. Sandra Niccoli. Firence: Leo S. Olschki, 1987.

—. Teologia platonica. Ur. Errico Vitale. Milano: Bompiani, 2011. Galilei, Galileo. Dialog o dveh glavnih sistemih sveta, ptolemajskem in kopernikanskem. Prevod Mojca Mihelič. Ljubljana: ZRC SAZU, 2009.

Hermes Trismegist. Corpus hermeticum. Prevedel Pavel Češarek. Zbirka Hieron. Ljubljana: Nova revija, 2001.

Machiavelli, Niccolò. Vladar. Prevod Niko Košir. Ljubljana: Slovenska matica, 2017.

Manetti, Giannozzo. Dignità ed eccellenza dell'uomo. Ur. Giuseppe Marcellino. Milano: Bompiani, 2018.

Mirandola, Giovanni Pico della. O človekovem dostojanstvu. Prevod Brane Senegačnik. Ljubljana: Družina, 1997.

Pascal, Blaise. Misli. Celje: Mohorjeva družba, 1980.

Petrarka, Francesco. Soneti in kancone. Prevod Alojz Gradnik. Koper: Primorska založba, 1954.

—. —Vzpon na Mont Ventoux«. Prevod Tomaž Potočnik. Keria: studia Latina et Graeca 16, št. 2 (2014): 107-115.

—. Moja skrivnost ali O skrivnem neskladju mojih stremljenj. Prevod Tomaž Potočnik. Ljubljana: Slovenska matica, 2020.

Platon. Zbrana dela. Prevod Gorazd Kocijančič. Ljubljana: KUD Logos, 2009. 
Salutati, Coluccio. Invectiva in Antonium Luscum vicentinum, ur. D. Moreni. Firence: Magheri, 1826.

- Epistolario di Coluccio Salutati, ur. Francesco Novati. Fonti per la Storia d'Italia. Zv. 1-4. Rim: Istituto storico italiano, 1891-1911. —. Colucii Salutati De seculo et religione, ur. Berthold Louis Ullman. Firence: Olschki, 1957.

Smith, Leonardo, ur. Epistolario di Pier Paolo Vergerio. Fonti per la Storia d'Italia. Rim: Istituto storico italiano per il Medio Evo, 1934. Vespasiano, da Bisticci. Vite di uomini illustri del secolo XV. Firence: Barbera, Bianchi \& comp, 1859.

Villani, Filippo. Le vite d'uomini illustri fiorentini. Ur. Giammaria Mazzuchelli. Benetke: Giambatista Pasquali, 1747.

\section{SEKUNDARNA LITERATURA}

Baron, Hans. Crisis of the Early Italian Renaissance. Princeton: Princeton University Press, 1966.

—. "Lo sfondo storico del Rinascimento fiorentino«. La Rinascita 1, št. 3 (1938): 50-72.

Cacciari, Massimo. La mente inquieta: Saggi sull'Umanesimo. Torino: Einaudi, 2019.

Canfora, Davide. Prima di Machiavelli: Politica e cultura in età umanistica. Rim: Laterza, 2005.

Cappelli, Guido, ur. La dignità e miseria dell'uomo nel pensiero europeo: Atti del Convegno internazionale (Madrid, 20-22 maggio 2004). Rim: Salerno editore, 2006.

- L'umanesimo italiano da Petrarca a Valla. Rim: Carrocci editore, 2019.

Cardini, Roberto, in Viti, Paolo, ur. Coluccio Salutati e Firenze. Firence: Mauro Pagliai Editore, 2008.

Cassirer, Ernst. Individuum und Kosmos in der Philosophie der Renaissance. Leipzig: Teubner, 1927.

Couliano, Ioan P. Eros et Magie à la Renaissance: 1489. Pariz: Flammarion, 1984.

De Robertis, Teresa, Giuliano Tanturli in Stefano Zamponi, ur. Coluccio Salutati e l'invenzione dell'umanesimo. Firence: Mandragora, 2008.

De Rosa, Daniela. Coluccio Salutati: Il cancelliere e il pensatore politico. Firence: La Nuova Italia, 1980.

Ebgi, Raphael, ur. Umanisti italiani: Pensiero e destino. Torino: Einaudi, 2016.

Garin, Eugenio. »Aristotelismo e platonismo del Rinascimento «. $\mathrm{La}$ Rinascita 2, št. 8/9 (1939): 641-671. 
— - ur. Filosofi italiani del Quattrocento. Firence: Le Monnier, 1942. - ur. I trattati morali di Coluccio Salutati. Firence: La Monnier, 1942.

—. Educazione umanistica in Italia. Rim: Laterza, 1975.

_. L'umanesimo italiano: Filosofia e vita civile nel Rinascimento. Rim: Laterza, 1993.

—. Spisi o humanizmu in renesansi. Ljubljana: šKUC, 1993.

—_. La cultura filosofica del Rinascimento italiano: Ricerche e documenti. Milano: Bompiani, 1994.

- La cultura del Rinascimento. Rim: Laterza, 2010.

Gentile, Giovanni. Studi sul Rinascimento. Firence: Sansoni, 1936.

Gigliucci, Roberto. Lo spettacolo della morte: Estetica e ideologia del macabro nella letteratura medievale. Anzio: De Rubeis, 1994.

Gombrich, Ernst H. »Botticelli’s Mythologies«. V: Symbolic Images: Studies in the Art of the Renaissance, II. London: Phaidon, 1972.

Griggio, Claudio. »Dalla lettera all'epistolario: Aspetti retorico-formali dell'epistolografia umanistica". V: Alla lettera: Teorie e pratiche epistolari dai greci al Novecento, ur. Adriana Chemello, 83-107. Milano: Guerini studio, 1998.

Hankins, James. Renaissance Civic Humanism: Reappraisals and Reflections. Cambridge: Cambridge University Press, 2000.

Kalan, Valentin. "Uvod«, 5-29. V: Dnevnik cesarja Marka Avrelija. Ljubljana: Slovenska matica, 1988.

Louth, Andrew. Izvori krščanskega mističnega izročila. Zbirka Hieron. Ljubljana: Nova revija, 1993.

Marzi, Demetrio. La cancelleria della repubblica fiorentina. Casciano: Cappelli, 1910.

Novati, Francesco. La giovinezza di Coluccio Salutati. Torino: Loescher, 1883 .

—_. »Aneddoti Viscontei«. Archivio storico lombardo, 35/19 (1908): 193-216.

Nuzzo, Armando, ur. Lettere di stato di Coluccio Salutati: Cancellierato fiorentino (1375-1406), 1-2. Rim: Istituto storico italiano per il Medio Evo, 2008.

Pellegrini, Marco. Umanesimo: Il lato incompiuto della modernità. Brescia: Morcelliana, 2015.

- Religione e umanesimo nel primo Rinascimento: Da Petrarca ad Alberti. Firence: Le Lettere, 2020.

Pocock, John Greville Agard. The Machiavellian Moment: Florentine Political Thought and the Atlantic Republican Tradition. Princeton: Princeton University Press, 1975. 
Rossi, Luca Carlo, ur. Le strade di Ercole: Itinerari umanistici e altri percorso; Seminario internazionale per i centenari di Coluccio Salutati e Lorenzo Valla (Bergamo 25-26 ottobre 2007). Firence: Sismel Edizioni del Galluzzo, 2010.

Simoniti, Primož. Humanizem na Slovenskem in slovenski humanisti do srede XVI. stoletja. Ljubljana: Slovenska matica, 1979.

Skinner, Quentin. Virtù rinascimentali. Bologna: Il Mulino, 2006.

Struever, Nancy S. Theory as Practice: Ethical Inquiry in the Renaissance. Chicago: University of Chicago Press, 1992.

Škamperle, Igor. »Lovec in odstrta Diana«. Poligrafi 2, št. 5/6 (1997): 5-21. —. Magična renesansa. Ljubljana: Študentska založba, 1999.

—_. "Tehnologija oblasti«. V: Machiavelli: Vladar, 128-140. Ljubljana: Slovenska matica, 2017.

Toussaint, Stephane. La liberté d'esprit: Fonction et condition des intellectuels humanistes. Pariz: Les Belles Lettres, 2019.

Ullman, Berthold Louis. The Humanism of Coluccio Salutati. Padova: Antenore, 1963.

Witt, Ronald G. Hercules at the Crossroads: The Life, Works, and Thought of Coluccio Salutati. Durham: Duke University press, 1983.

MODERNI SPISI

Arendt, Hannah. Men in Dark Times. New York: Harcourt Brace \& World, 1968.

- Humanitas mundi: Scritti su Karl Jaspers. Ur. Rosalia Peluso. Milano: Mimesis, 2015.

Chomsky, Noam. »Odgovornost intelektualcev«. V: Somrak demokracije, 45-68. Ljubljana: Studia humanitatis, 1997.

Gilson, Étienne. Ljubezen filozofov. Ljubljana: Družina, 1996.

—. Duh srednjeveške filozofije. Ljubljana: Družina, 2002.

Havel, Vaclav. »Politika in vest«. 20oo: Revija za krščanstvo in kulturo 46-47 (1989): 22-35.

Oestereich, Gerhard. Storia dei diritti umani e delle libertà fondamentali. Rim: Laterza, 2002.

Ordine, Nuccio. Koristnost nekoristnega. Ljubljana: Cankarjeva založba, 2015.

Singer, Peter. Praktična etika. Ljubljana: Krtina, 2009.

Weber, Max. La politica come professione. Turin: Einaudi, 2001. 


\section{IZVLEČEK}

Vprašanje (dis)kontinuitete med etiko in politiko je civilni živec renesančnega humanizma v historični ontogenezi, ki se začne s Salutatijem, razvija s Ficinom in sklepa z Machiavellijem. Tragično sirensko petje človeškega bivanja vseskozi zapeljuje, a nikdar ne preglasi vzgornih upov k praksi usmerjene človeškosti, ki spekulacijo uresničuje skozi dejavnost, kontemplacijo udejanja skozi politiko, sveto izpričuje skozi posvetnost. Humanistična duhovna in filozofska prenova ciceronskega nauka o dobrem delovanju na pragu modernosti nemirno, pa vendar srečno pripelje antropološko vexata quaestio skozi Scilo in Karibdo družbene etike, nihajoče med jajcem in jabolkom ( $a b$ ovo usque ad mala) Salutatijevega voluntarističnega optimizma, Ficinovega novoplatonizma in Machiavellijevega antropološkega pesimizma, med zemljo, nebom in breznom. Civilni humanizem še danes budi in bodri vse, ki se v somraku človeškosti še trudijo služiti kvalificiranemu življenju.

KLJUČNE BESEDE: civilni humanizem, dejavno življenje, družbena etika, novoplatonizem, Salutati, Ficino, Machiavelli 
SALUTATI, FICINO, AND MACHIAVELLI:

FROM THE EGG TO THE APPLE OF CIVIC HUMANISM

\section{ABSTRACT}

The question of (dis)continuity between ethics and politics is the civic nerve of Renaissance humanism as reflected in the historical ontogenesis which begins with Salutati, developes with Ficino, and ends with Machiavelli. The tragic siren song of human being tempts, but never drowns out the upcurrent hopefulness of practical humanity, which realizes speculation through action, contemplation through politics, the sacred through the secular. The humanistic spiritual and philosophical reinterpretation of Cicero's doctrine of good action at the doorstep of modernity drives the anthropological question through the Scylla and Charybdis of social ethics, swinging from egg to apple (ab ovo usque ad mala) of Salutati's voluntaristic optimism, Ficino's neoplatonism, and Machiavelli's anthropological pessimism, between earh, heaven, and the void. The civic humanism awakes and encourages those who strive to serve qualified humanity in the twilight of humanness.

KEYWORDS: civic humanism, human action, social ethics, neoplatonism, Salutati, Ficino, Machiavelli 